\title{
The Dynamic Linkage between Money Market, Capital Market and Economic Growth in Ghana: New Lessons Relearned
}

\author{
Isaac A. Ogbuji ${ }^{\star}$, Ekundayo P. Mesagan* ${ }^{*}$, and Yasiru O. Alimi ${ }^{\odot}$ \\ \$. Department of Finance, University of Lagos, Nigeria \\ School of Management and Social Sciences, Pan Atlantic University, Lekki, Lagos, Nigeria \\ $\Upsilon^{\circ}$ Department of Economics, Lead City University, Nigeria
}

Submitted: December 17, $2019 \bullet$ Accepted: April 6, 2020

\begin{abstract}
This study is a comparative analysis of the effects of money and capital markets on the Ghanaian economy covering the period from 1991 to 2017 using the dynamic Auto Regressive Distributed Lag (ARDL) framework. Empirical results confirmed the existence of a unique and stable long-run relationship between the money market, capital market and economic growth. In respect of money market indicators, findings confirmed that monetary policy and treasury bills rate have had negative but significant impact on growth in the short- and long-run respectively. More so, total liquidity negatively and significantly influenced the Ghanaian economy both in the short- and in the long run. Both market capitalisation and total value of stock traded, as proxies of capital market, had positive and significant effects on short-run growth, while both indicators as well as stock market turnover negatively and insignificantly affected long-run growth. This means that capital market exerts a short-run impact on the country's economy, while money market exerts both short- and long-run impacts. The lesson relearned is that the money market propels the Ghanaian economy better than the capital market.
\end{abstract}

JEL classification: E13, E43, E51, G20, G47

Keywords: Financial Development; Money Market; Capital Market; Economic Growth

${ }^{*}$ Corresponding Author. E-mail: profdayoms@yahoo.com 


\section{Introduction}

One of the key factors in ensuring sustainable growth is the development of financial markets since they are capable of diverting idle financial resources from surplus areas to productive ends (Goldsmith, 1969; Durusu-Ciftci et al., 2017; Mesagan et al., 2018b; Eregha and Mesagan, 2020). Gibson and Tsakalotos (1994) posited that the liberalization of financial markets could improve savings, investments and efficient allocation of financial resources which, in turn, leads to rapid growth of the economy. The theory about the relationship between growth and financial market development originates from Schumpeter (1911), who pointed out that financial institutions played a crucial role in the economy through financial resources' allocation. Moreover, scholars such as McKinnon (1973); Levine and Zervos (1996); Cooray (2010); Beck and Levine (2004); Narayan and Narayan (2013), as well as Isola and Mesagan (2018) posited that the financial sector provided a direct stimulus that is necessary for growth. Other studies by, for instance, Singh (1997); Nili and Rastad (2007); Enisan and Olufisayo (2009); Adusei (2014); Owusu and Odhiambo (2014b); Mesagan and Nwachukwu (2018), as well as Samargandi et al. (2020) confirmed that the situation was quite different in developing countries where financial markets were poorly organised. Hence, their output growth was not substantially enhanced.

Over the past few decades, scholars from developing nations such as Bolbol et al. (2005); Odhiambo (2010b); Acquah-Sam and Salami (2014); Mesagan and Shobande (2016); Mesagan et al. (2019a); Yusuf et al. (2020), among others, have been developing more interest in examining the link between growth and the financial sector in order to verify what studies by, for instance, Levine and Zervos (1996); Shaw (1973), established for developed nations. Although this is interesting, there have only been few studies analysing the comparative impacts of money and capital markets on developing countries'economies. Therefore, the present study empirically investigates these assumptions with respect to the Ghanaian economy using the ARDL framework having confirmed the integration of the variables to be of order zero and one. This method has also been chosen due to its efficiency when dealing with small and finite samples with endogenous regressors (Haug, 2002). It has also been affirmed that ARDL allows dependent and independent variables to have unrestricted numbers of lags (Pesaran et al., 2001).

The study contributes to the body of knowledge by investigating individual contributions of both money and capital markets to the development of Ghana. This is crucial because promoting economic growth through both markets provides means for economic diversification. As noted in Charles et al. (2018), as well as Mesagan et al. (2019b), economic diversification creates an opportunity for a nation to overcome the challenges and problems resulting from being a mono-product economy and launch itself on the path of sustainable growth. To this end, the present study selects three financial market indicators from both money and capital markets in order to conduct the analysis using the ARDL framework. The methodology is also very important as it changes the narratives 
from the static analyses, that are often used in the literature, and suggests the short- and long-run adjustments towards introducing appropriate policies. The money market indicators are total liquidity, treasury bills rate, and monetary policy rate while the capital market fundamentals are stock turnover, total values of stock traded and market capitalization. The remaining sections of this research paper are divided into four parts in the following order. The second section reviews literature relevant to this study. The third section discusses the methodology. Section 4 presents the empirical results and discussion of the study, while section 5 presents the conclusion.

\section{Literature Review}

Empirical literature analysing the linkage between economic growth and financial development leans more towards the stock market indicators while little analysis has been provided regarding how money and capital markets affect overall growth, especially in less developed nations. For instance, the money market provides the means for trading short-term debt instruments such as, among others, Certificate of Deposits (CODs) and Treasury Bills (TBs). Whereas capital market provides the platform for selling long-term instruments, where capital for providing investments that require long gestation periods can be raised (Omojolaibi et al. 2016). Findings of the past literature have been largely mixed and mostly inconclusive. Studies such as Bonfiglioli and Mendicino (2004); Brasoveanu et al. (2008); Vazakidis and Adamopoulos (2009) found a direct connection between growth and financial development, while Echekoba et al. (2013); Owusu and Odhiambo (2014b); Adusei (2014); Mesagan et al. (2018a), and Samargandi et al. (2020) found a negative link. A tabular presentation of relevant and related studies reviewed is presented in Table 1 .

Table 1: Tabular Presentation of Literature Review

\begin{tabular}{|c|c|c|c|}
\hline Authors & $\begin{array}{l}\text { Region/ } \\
\text { Country/ } \\
\text { Scope }\end{array}$ & Methodology & Major Findings \\
\hline Levine (1997) & $\begin{array}{l}77 \text { countries } \\
(1960-1989)\end{array}$ & $\begin{array}{l}\text { Cross-section } \\
\text { regression analysis }\end{array}$ & $\begin{array}{l}\text { Financial market directly enhanced } \\
\text { long-run growth through financial } \\
\text { intermediaries. }\end{array}$ \\
\hline Vazakidis and & France & Granger causality & Positive impact \\
\hline \begin{tabular}{|l} 
Adamopoulos \\
2009
\end{tabular} & $(1965-2007)$ & $\begin{array}{l}\text { and Vector Error } \\
\text { Correction Model } \\
\text { (VECM) }\end{array}$ & $\begin{array}{l}\text { Causality direction - Economic growth } \\
\text { to Stock market development }\end{array}$ \\
\hline Mishra et al. & $\begin{array}{l}\text { India (1991: Q1 - } \\
\text { 2010: Q1) }\end{array}$ & $\begin{array}{l}\text { Multiple } \\
\text { regression- } \\
\text { ordinary least } \\
\text { square }\end{array}$ & $\begin{array}{l}\text { Positive impact - capital market to } \\
\text { output growth }\end{array}$ \\
\hline
\end{tabular}


Table 1. Continue

\begin{tabular}{|c|c|c|c|}
\hline Authors & $\begin{array}{l}\text { Region/ } \\
\text { Country/ } \\
\text { Scope }\end{array}$ & Methodology & Major Findings \\
\hline $\begin{array}{l}\text { Brasoveanu et al. } \\
(2008)\end{array}$ & $\begin{array}{l}\text { Romania } \\
\text { (2000: Q1 - } \\
\text { 2006: Q2) }\end{array}$ & $\begin{array}{l}\text { Vector } \\
\text { autoregressive } \\
\text { (VAR) models }\end{array}$ & $\begin{array}{l}\text { They reported a positive feedback } \\
\text { effect between capital market and } \\
\text { economic growth. Meanwhile, a } \\
\text { stronger link is reported from output } \\
\text { growth to capital market. }\end{array}$ \\
\hline $\begin{array}{l}\text { Bolbol et al. } \\
(2005)\end{array}$ & $\begin{array}{l}\text { Egypt } \\
(1974-2012)\end{array}$ & $\begin{array}{l}\text { Multiple } \\
\text { regression analysis }\end{array}$ & $\begin{array}{l}\text { Bank-based financial indicators } \\
\text { negatively affected total factor } \\
\text { productivity but had positive effect via } \\
\text { the income channel. However, net } \\
\text { private resource flows positively } \\
\text { strengthened the links between } \\
\text { market-based indicators and total } \\
\text { factor productivity. }\end{array}$ \\
\hline $\begin{array}{l}\text { Azarmi et al. } \\
(2005)\end{array}$ & India (1981-2001) & $\begin{array}{l}\text { Multiple } \\
\text { regression analysis }\end{array}$ & $\begin{array}{l}\text { Stock market positively influenced } \\
\text { growth during the pre-liberalization } \\
\text { era (1981-1990) while its impact was } \\
\text { negative during the post-liberalization } \\
\text { (1991-2001). }\end{array}$ \\
\hline $\begin{array}{l}\text { Shahbaz et al. } \\
(2008)\end{array}$ & $\begin{array}{l}\text { Pakistan } \\
(1971-2006)\end{array}$ & $\begin{array}{l}\text { Auto regressive } \\
\text { distributed lag } \\
\text { (ARDL) }\end{array}$ & $\begin{array}{l}\text { Positive impact - from market } \\
\text { capitalization to economic growth }\end{array}$ \\
\hline Owusu (2016) & $\begin{array}{l}\text { Nigeria } \\
(1987-2014)\end{array}$ & $\begin{array}{l}\text { Auto regressive } \\
\text { distributed lag } \\
\text { (ARDL) }\end{array}$ & $\begin{array}{l}\text { Using real stock market capitalization, } \\
\text { real stock value traded and stock } \\
\text { market turnover ratio as measures of } \\
\text { stock market indicators, the study } \\
\text { reported that the result was mixed and } \\
\text { inconclusive. }\end{array}$ \\
\hline $\begin{array}{l}\text { Enisan and } \\
\text { Olufisayo }(2009)\end{array}$ & $\begin{array}{l}\text { Seven selected } \\
\text { sub-Saharan } \\
\text { African countries } \\
(1980-2004)\end{array}$ & $\begin{array}{l}\text { ARDL, } \\
\text { Granger-causality } \\
\text { tests based on } \\
\text { vector error } \\
\text { correction model }\end{array}$ & $\begin{array}{l}\text { Cointegration was found between stock } \\
\text { market and income growth in Egypt } \\
\text { and South Africa. The VECM result } \\
\text { showed that output growth enhanced } \\
\text { stock market development in South } \\
\text { Africa and Egypt. While a } \\
\text { bidirectional nexus was found for } \\
\text { Zimbabwe, Morocco, Kenya, and Cote } \\
\text { D'Ivoire. It however found no linkage } \\
\text { between growth the Nigerian stock } \\
\text { market. }\end{array}$ \\
\hline Aboudou (2009) & $\begin{array}{l}\text { West African } \\
\text { Monetary Union } \\
\text { (WAMU) } \\
\text { Countries }\end{array}$ & $\begin{array}{l}\text { Granger } \\
\text { non-causality test } \\
\text { (Toda \& } \\
\text { Yamamoto, 1995) }\end{array}$ & $\begin{array}{l}\text { Both stocks value and market } \\
\text { capitalization strongly determined } \\
\text { economic growth in WAMU. }\end{array}$ \\
\hline
\end{tabular}


Table 1. Continue

\begin{tabular}{|c|c|c|c|}
\hline Authors & $\begin{array}{l}\text { Region/ } \\
\text { Country/ } \\
\text { Scope }\end{array}$ & Methodology & Major Findings \\
\hline Alimi and Yinusa & $\begin{array}{l}\text { Nigeria } \\
(1970-2013)\end{array}$ & VAR & $\begin{array}{l}\text { Shocks in domestic credit to private } \\
\text { sector significantly influenced output } \\
\text { growth. Likewise, income responded } \\
\text { greatly to shocks in money supply. }\end{array}$ \\
\hline $\begin{array}{l}\text { Yinusa and Alimi } \\
(2014)\end{array}$ & $\begin{array}{l}\text { Nigeria } \\
(1981-2012)\end{array}$ & $\begin{array}{l}\text { Error correction } \\
\text { model }\end{array}$ & $\begin{array}{l}\text { Financial development failed to reduce } \\
\text { poverty and inequality. Thus, the } \\
\text { Greenwood and Jovanovich hypothesis } \\
\text { did not hold in Nigeria. }\end{array}$ \\
\hline $\begin{array}{l}\text { Churchill et al. } \\
\text { (2013) }\end{array}$ & $\begin{array}{l}\text { Ghana } \\
(1991-2006)\end{array}$ & $\begin{array}{l}\text { Co-integration } \\
\text { technique and } \\
\text { Vector error } \\
\text { correction model } \\
\text { (VECM) }\end{array}$ & $\begin{array}{l}\text { A unidirectional relationship was } \\
\text { reported from economic growth to the } \\
\text { stock market capitalization. }\end{array}$ \\
\hline Osei (2005) & $\begin{array}{l}\text { Ghana (1991: Q1 } \\
\text { - 2003: Q4) }\end{array}$ & $\begin{array}{l}\text { Vector } \\
\text { autoregressive } \\
\text { (VAR) technique }\end{array}$ & $\begin{array}{l}\text { Stock market performance enhanced } \\
\text { income growth }\end{array}$ \\
\hline $\begin{array}{l}\text { Owusu and } \\
\text { Odhiambo } \\
(2014 \mathrm{~b})\end{array}$ & Ghana & $\mathrm{ARDL}$ & $\begin{array}{l}\text { No positive impact was found in both } \\
\text { in the short- and the long- run. } \\
\text { However, private sector credit as a } \\
\text { measure of bank-based indices } \\
\text { enhanced economic growth. }\end{array}$ \\
\hline \begin{tabular}{|l|} 
Dziwornu and \\
Awunyo-Vitor \\
$(2013)$ \\
\end{tabular} & $\begin{array}{l}\text { Ghana } \\
(1990-2012)\end{array}$ & Granger causality & $\begin{array}{l}\text { Stock market positively impacted } \\
\text { income growth. }\end{array}$ \\
\hline $\begin{array}{l}\text { Asante et al. } \\
2011) \\
\end{array}$ & $\begin{array}{l}\text { Ghana } \\
(1992-2009)\end{array}$ & $\begin{array}{l}\text { ARDL and } \\
\text { dynamic OLS }\end{array}$ & $\begin{array}{l}\text { Bank competition and stock market } \\
\text { exerted positive impact on income. }\end{array}$ \\
\hline \begin{tabular}{|l} 
Acquah-Sam and \\
Salami $(2014)$
\end{tabular} & $\begin{array}{l}\text { Ghana (1991: Q1 } \\
\text { - 2011: Q4) }\end{array}$ & $\begin{array}{l}\text { Structural } \\
\text { equation modeling }\end{array}$ & $\begin{array}{l}\text { Bi-causal relationship - capital market } \\
\text { and income growth. }\end{array}$ \\
\hline Adusei (2014) & $\begin{array}{l}\text { Ghana (2006: Q1 } \\
\text { - 2013: Q2) }\end{array}$ & $\mathrm{ARDL}$ & $\begin{array}{l}\text { Negative impact - stock market on } \\
\text { long-run income growth. Also, stock } \\
\text { market unidirectionally caused output } \\
\text { growth. }\end{array}$ \\
\hline \begin{tabular}{|l|} 
Mesagan et al. \\
2019a)
\end{tabular} & $\begin{array}{l}\text { Ghana } \\
(1991-2017)\end{array}$ & ARDL & $\begin{array}{l}\text { In the long-run, long-term financial } \\
\text { indices perform better than short-term } \\
\text { instruments in boosting output growth } \\
\text { while both measures enhanced growth } \\
\text { positively in the short-run. }\end{array}$ \\
\hline Mishra (2020) & India (1991-2015) & $\begin{array}{l}\text { Regression } \\
\text { Analysis }\end{array}$ & $\begin{array}{l}\text { Financial development determined } \\
\text { long-run growth. }\end{array}$ \\
\hline
\end{tabular}


Table 1. Continue

\begin{tabular}{|c|c|c|c|}
\hline Authors & $\begin{array}{l}\text { Region/ } \\
\text { Country/ } \\
\text { Scope }\end{array}$ & Methodology & Major Findings \\
\hline Yusuf et al. (2020) & $\begin{array}{l}\text { Nigeria } \\
(1985-2018)\end{array}$ & $\begin{array}{l}\text { Vector } \\
\text { Autoregressive } \\
\text { (VAR) Framework }\end{array}$ & $\begin{array}{l}\text { Financial deepening unidirectionally } \\
\text { caused stock market returns during } \\
\text { democratic era while there existed } \\
\text { mutual causal relationship between } \\
\text { both during the military regime. }\end{array}$ \\
\hline $\begin{array}{l}\text { Samargandi et al. } \\
(2020)\end{array}$ & $\begin{array}{l}\text { BRICS (1989: Q1 } \\
\text { - 2012: Q4) }\end{array}$ & $\begin{array}{l}\text { Global Vector } \\
\text { Autoregressive } \\
\text { Framework } \\
\text { (GVAR) }\end{array}$ & $\begin{array}{l}\text { Money supply indicators and equity } \\
\text { market could not predict financial } \\
\text { market impact on growth among the } \\
\text { BRICS nations. }\end{array}$ \\
\hline
\end{tabular}

Note: Compiled by authors.

\section{Methodology}

\subsection{Data Description and Model Specification}

The improvement of financial markets through both capital market and money market is expected to enhance the economic activities of a nation. In to the light of this contention, this study specifies two models to establish the existing links among capital market, money market and income growth. This paper adapts Beck et al. (2000); Owusu and Odhiambo (2014ba); Mesagan et al. (2019a) growth and stock market models. The real income per capita is assumed to be a function of a vector of money market indicators (i.e. banking rate, total liquidity, and treasury bills rate) and capital market indicators (i.e. market capitalisation, total stock traded values and turnover of stock). In addition, we control for other economic indices (e.g. capital investment and foreign direct investment) because they are essential drivers of economic growth.

$$
\mathrm{PCI}_{t}=\beta_{0}+\varphi^{\prime} \mathrm{MMI}_{t}+\theta^{\prime} \mathrm{CMI}_{t}+\varphi_{1} \mathrm{CAPY}_{t}+\varphi_{2} \mathrm{FDIY}_{t}+\mu_{t}
$$

Where: PCI = real income per capita; $\mathrm{MMI}=$ vector of money market indices represented by banking rate proxy by monetary policy rate (BR), 3-month treasury bills rate (TBRT), total liquidity measured the growth in broad money $(\mathrm{BM}) ; \mathrm{CMI}=$ a vector of capital market variables denoted by market capitalization as a ratio to GDP (MCY), total stock traded value to GDP (TSTY), and stock market turnover (SMTR); CAPY = capital investment proxy by gross fixed capital formation to GDP; FDIY = net foreign direct investment inflows to GDP; $\beta_{0}=$ constant; $\varphi^{\prime}=$ vector of coefficients of money market indices; $\theta^{\prime}=$ vector of coefficients of capital market indicators; $\varphi_{1}, \varphi_{2}=$ parameters of capital and FDI; $t=$ time; $\mu=$ error term.

Secondary data covering the period from 1991 to 2017 is analysed in this study. The 
period covers the financial liberalization era in Ghana. The various data were sourced from the World Bank's World Development Indicators (World Development Indicators, 2019) as well as the Bank of Ghana (Bank of Ghana, 2019). Figure 1 and 2 present datasets for money and capital markets indices vis-à-vis per capita income growth in Ghana during the period of 1991-2017.

Figure 1: Money Market Instrument and Income Growth in Ghana, 1991-2017

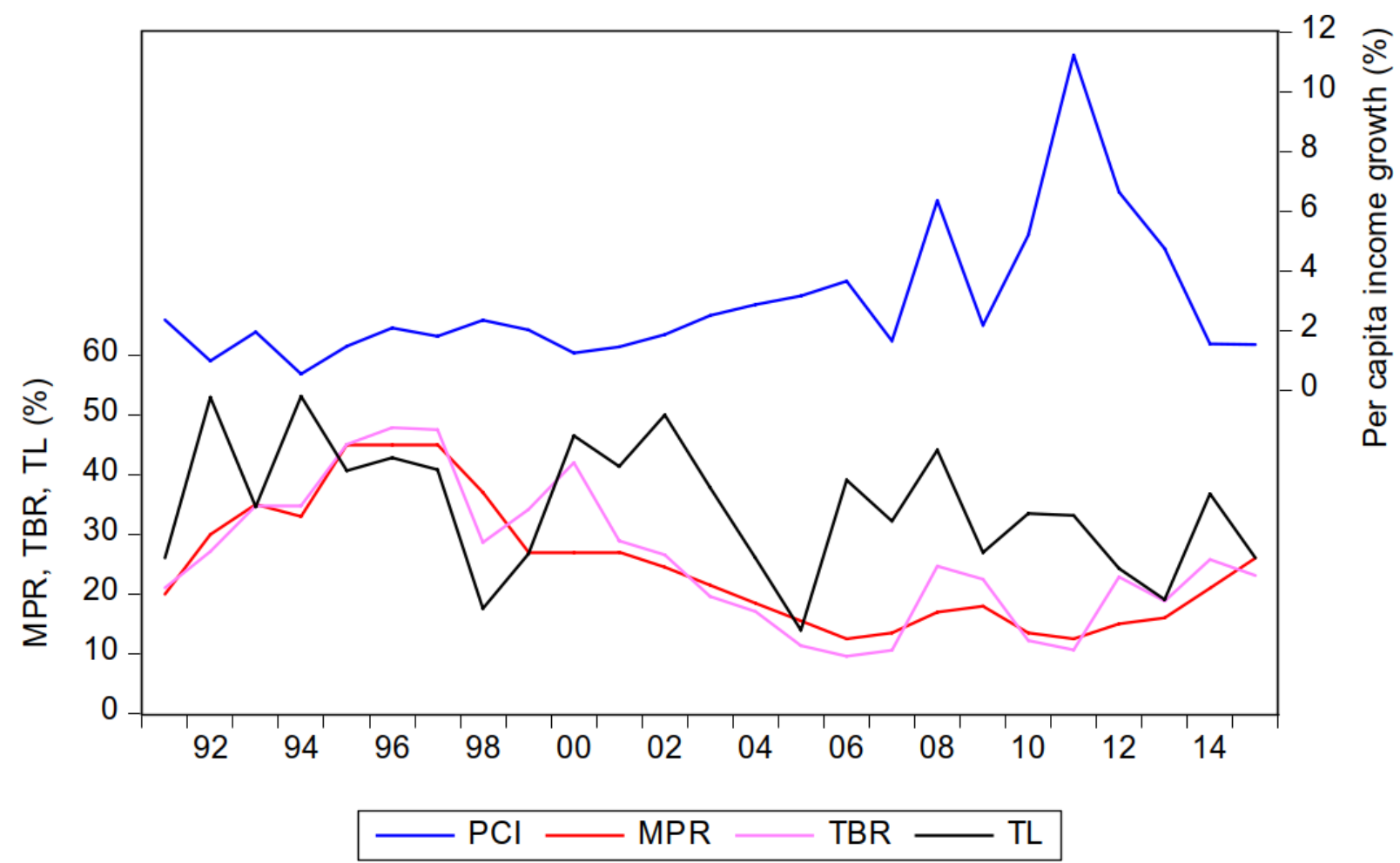

Note: MPR: Monetary Policy Rate; TBR: Treasury Bill Rate; TL: Total Liquidity.

Source: Data are from Bank of Ghana (2019) and World Development Indicators (2019)

The summary statistics of the variables in regards to the mean, standard deviation, maximum and minimum are presented in Table 2. The mean growth value of real per capita GDP stands at $2.96 \%$ for the period from 1991 to 2017 , which indicates that the rate at which real income per capita grows is low. Meanwhile, for the money market indicators, their average growth rates are $24.64 \%, 25.91 \%$ and $34.66 \%$ for bank rate, treasury bills rate and total liquidity respectively. As for the stock market indices, the corresponding mean values for market capitalization, total stock traded value and capital market turnover are $10.72 \%, 0.42 \%$ and $5.43 \%$ respectively. The growth rate of capital market variables is low relative to the averages of its counterpart. The results from the correlation matrix presented in Table 3 reveal the absence of multicollinearity problem in the model.

In terms of 'a priori' expectations, we expect an indirect relationship between bank rate and real income per capita. What follows is that a higher bank rate will cause an 
Figure 2: Capital Marker Indicators and Output Growth in Ghana, 1991-2017

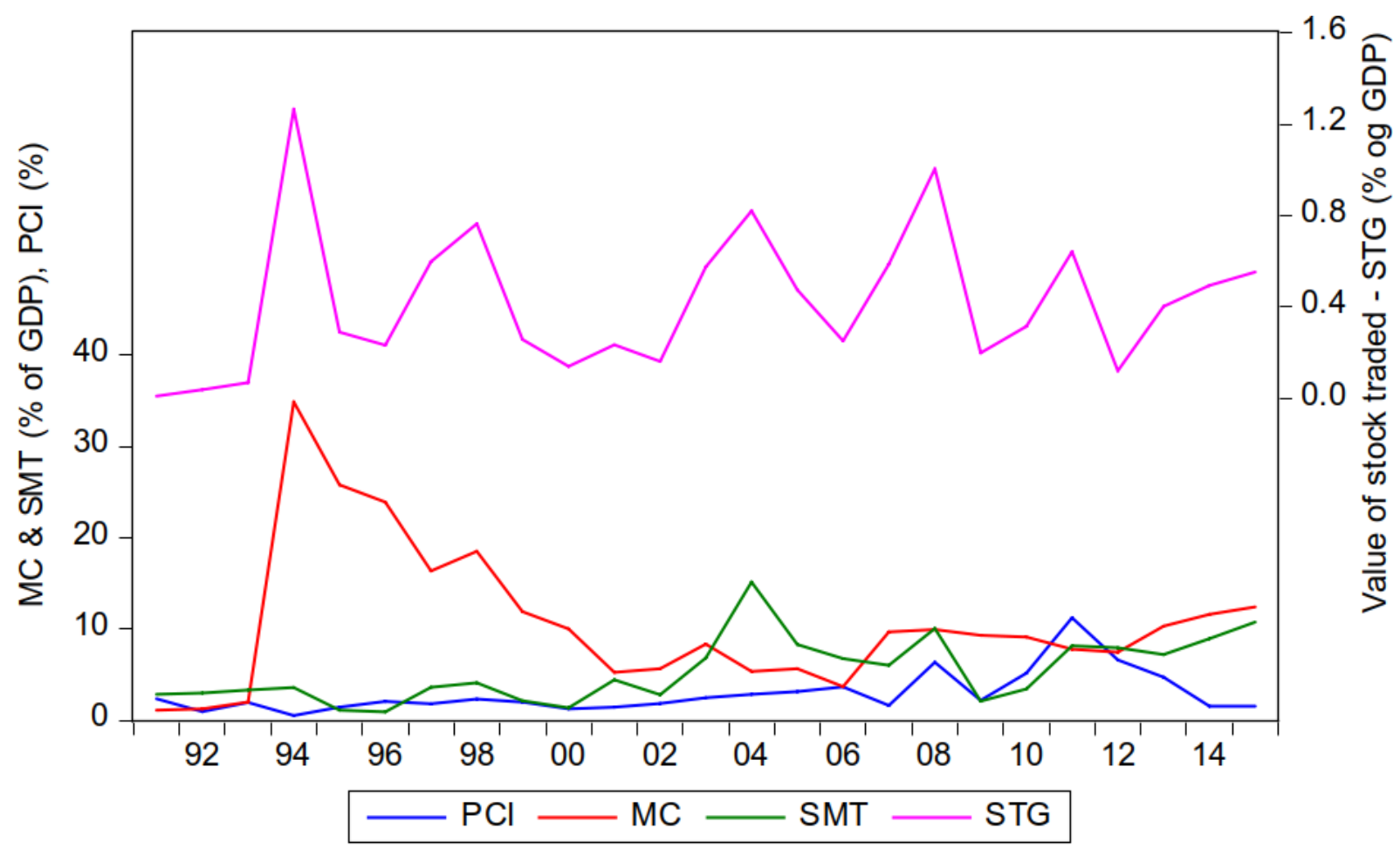

Note: MC: Market Capitalization; SMT: Stock Market Turnover; PCI: Per Capita Income Growth. Source: Data are from Bank of Ghana (2019) and World Development Indicators (2019)

Table 2: Summary Statistics and Definition of Variables

\begin{tabular}{|c|c|c|c|c|c|}
\hline Regressors & Definition & Mean & Std. Dev. & Max. & Min. \\
\hline \multicolumn{6}{|c|}{ Dependent variable } \\
\hline$P C I$ & GDP growth Per Capita (PCI, yearly growth \%) & 2.96 & 2.34 & 11.25 & 0.57 \\
\hline \multicolumn{6}{|c|}{ Money market variables } \\
\hline$B R$ & Bank rate proxy by Monetary policy rate $(\mathrm{BR}, \%)$ & 24.64 & 10.41 & 45 & 12.5 \\
\hline$T B R T$ & Treasury Bills Rate (TBRT, \%) & 25.91 & 11.50 & 47.88 & 9.6 \\
\hline$B M$ & Total liquidity proxy by broad money (BM, \%) & 34.66 & 10.77 & 53.13 & 13.99 \\
\hline \multicolumn{6}{|c|}{ Capital market indicators } \\
\hline$M C Y$ & Market capitalization as \% of GDP (MCY) & 10.72 & 7.98 & 34.89 & 1.15 \\
\hline$T S T Y$ & Total stock traded value to GDP (TSTY) & 0.42 & 0.31 & 1.27 & 0.01 \\
\hline$S M T R$ & Stock market turnover (SMTR) & 5.43 & 3.54 & 15.18 & 0.97 \\
\hline \multicolumn{6}{|c|}{ Control variables } \\
\hline$C A P Y$ & $\begin{array}{l}\text { Capital investment proxy by gross fixed capital } \\
\text { formation to GDP (CAPY) }\end{array}$ & 22.94 & 4.08 & 30.93 & 12.74 \\
\hline$F D I$ & Net foreign direct investment inflow to GDP & 4.12 & 3.18 & 9.52 & 0.30 \\
\hline
\end{tabular}

Source: Authors' Compilation (2020).

increase in the cost of doing business, thereby limiting the effectiveness of fund allocated from the unproductive source to productive sources. Hence, such negative relationship 
may retard economic growth. Also, an increase in treasury bills rate may slow down the growth rate of income because it has a contractionary effect on the economy, and the funds might not even be invested in capital projects. On the other hand, it boosts up output growth rate given that the total monetary value of the money market instruments (i.e. purchase amount and interest) is readily accessible to economic resource use geared towards the expansion of economic growth. Also, an increase in total liquidity measured by growth rate of money supply enhances resource allocation which has the capacity of improving the real per capita income.

Table 3: Correlation Analysis

\begin{tabular}{|c|c|c|c|c|c|c|c|c|c|}
\hline & $P C I$ & $B R$ & $T B R T$ & $B M$ & $M C Y$ & $T S T Y$ & $S M T R$ & $C A P Y$ & $F D I Y$ \\
\hline$P C I$ & 1.000 & & & & & & & & \\
\hline$B R$ & -0.537 & 1.000 & & & & & & & \\
\hline$T B R T$ & -0.484 & 0.906 & 1.000 & & & & & & \\
\hline$B M$ & -0.264 & 0.353 & 0.439 & 1.000 & & & & & \\
\hline$M C Y$ & -0.233 & 0.585 & 0.553 & 0.231 & 1.000 & & & & \\
\hline$T S T Y$ & 0.133 & -0.020 & -0.102 & 0.025 & 0.524 & 1.000 & & & \\
\hline$S M T R$ & 0.382 & -0.535 & -0.572 & -0.367 & -0.274 & 0.484 & 1.000 & & \\
\hline$C A P Y$ & 0.379 & -0.269 & -0.209 & -0.454 & 0.008 & 0.259 & 0.559 & 1.000 & \\
\hline$F D I Y$ & 0.511 & -0.509 & -0.353 & -0.197 & 0.050 & 0.262 & 0.363 & 0.314 & 1.000 \\
\hline
\end{tabular}

Source: Authors' Compilation (2020).

According to Beck et al. (2000), the stock traded value to the economic size of a country measures the liquidity rate in the country's capital market. A high rate of liquidity enhances the investment incentive since it improves the rate upon which economic resources are efficiently allocated, and invariables boost income growth Owusu and Odhiambo, $2014 \mathrm{~b}$ a). As regards the stock market volume, it is captured by total market capitalization as a percentage of total annual monetary income earned in an economy. If the size of the market increases, a boost in the capital base of listed firms is expected, which then provides more growth stimulus in the economy. Again, the stock market is captured with the total stocks traded as a ratio of market capitalization and it is expected to stimulate economic growth by providing firms with more financial resources. In the same vein, the capital market turnover is expected to spur economic growth like other indices. For the control variables, capital investment in the model is proxied by the total value added to existing stock of capital, which enhances growth. In addition, foreign direct investment is expected to enhance income growth as it becomes an effective and efficient channel for transferring technology to the less developed nations.

\subsection{Estimation Techniques}

The first step is to find the stationarity level of all the times series regressors since it is critical to the estimation process. This is crucial because non-stationary regressors can produce a misleading result and nonsensical conclusion. Again, its result gives credence 
to the use of the ARDL framework employed in this study. The Augmented Dickey Fuller (ADF) test from Dickey and Fuller (1979), has been employed for this purpose. Thus, the unit root test results presented in Table 4 suggest that the regressors are stationary at first difference, except total traded stock value, capital investment and total liquidity proxy by broad money to GDP, which are stationary at levels.

Table 4: Stationarity tests of regressors using Augmented Dickey-Fuller (ADF)

\begin{tabular}{|c|c|c|c|c|c|c|c|c|}
\hline \multirow[b]{2}{*}{ Regressors } & \multicolumn{4}{|c|}{ Level } & \multicolumn{3}{|c|}{ First Difference } & \multirow[b]{2}{*}{ Status } \\
\hline & No Tre & end & Tren & & No Trend & Trenc & & \\
\hline$P C I$ & $-2.143(0)$ & {$[-2.992]$} & $-3.201(0)$ & {$[-3.612]$} & ] $-6.332^{* *(0)}[-2.998]$ & $-6.270^{* *}(0)$ & {$[-3.622]$} & $\mathrm{I}(1)$ \\
\hline$B R$ & $-1.537(1)$ & {$[-2.998]$} & $-2.067(0)$ & {$[-3.612]$} & $-3.648 *(0) \quad[-2.998]$ & $-3.733^{*}(3)$ & {$[-3.659]$} & $\mathrm{I}(1)$ \\
\hline$T B R T$ & $-1.714(0)$ & {$[-2.992]$} & $-2.562(0)$ & {$[-3.612]$} & $-4.923^{* *}(0)[-2.998]$ & $-3.972^{* *}(1)$ & {$[-3.633]$} & $\mathrm{I}(1)$ \\
\hline$B M$ & $-4.187^{* *}(0)$ & {$[-2.992]$} & $-4.512^{* *}(4)$ & {$[-3.659]$} & ] - & - & & $\mathrm{I}(0)$ \\
\hline$M C Y$ & $-2.739(0)$ & {$[-2.992]$} & $-3.005(1)$ & {$[-3.622]$} & $-5.615^{* *(0)}[-2.998]$ & $-5.533^{* *}(0)$ & {$[-3.622]$} & $\mathrm{I}(1)$ \\
\hline$T S T Y$ & $-5.236^{* *}(1)$ & {$[-2.998]$} & $-5.094 * *(1)$ & {$[-3.622]$} & - & - & & $\mathrm{I}(0)$ \\
\hline$S M T R$ & $-2.428(0)$ & {$[-2.992]$} & $-3.470(0)$ & {$[-3.612]$} & $-5.404^{* *}(1)[-3.005]$ & $-5.289^{* *}(1)$ & {$[-3.633]$} & $\mathrm{I}(1)$ \\
\hline$C A P Y$ & $-3.349 *(0)$ & {$[-2.992]$} & $-3.759 *(0)$ & {$[-3.612]$} & - & - & & $\mathrm{I}(0)$ \\
\hline$F D I Y$ & $-1.026(0)$ & [-2.992] & $-2.350(1)$ & {$[-3.622]$} & $-4.089^{* *}(0)[-2.998]$ & $-3.986^{* *}(0)$ & {$[-3.622]$} & $\mathrm{I}(1)$ \\
\hline
\end{tabular}

Note: ${ }^{* *}$ and ${ }^{*}$ signifies $1 \%$ and $5 \%$ significance level correspondingly. The values before the brackets "()" is the ADF test statistics. The brackets "()" signifies the lag length.

Source: Authors' Compilation (2020).

The outcomes of the unit root test, which combine both integration at order zero and one, suggest the use of the ARDL bounds test framework. Additionally, these estimation methods have been adopted due to the following features: (i) its application to empirical study is quite simple and it also brings into play the ordinary least square methods for estimating the cointegration relationship; (ii) the test of cointegration (i.e. long-run relationships) existence among regressors can be conducted even if the unit root outcomes indicate stationarity at levels or first differences or the combination of both; (iii) the method is found as a good and efficient estimator for empirical studies having small and finite samples; (iv) likewise, it is more relevant for studies that have its regressors as an endogenous variable; (v) it allows dependent and independent variables to have unrestricted numbers of lags (Pesaran et al., 2001; Haug, 2002; Sakyi et al., 2015). Based on the unrestricted error correction model, the ARDL bound test approach expresses our empirical model as:

$$
\begin{gathered}
\Delta \mathrm{PCI}_{t}=C_{1}+\sum_{i=1}^{p} \delta_{i} \Delta \mathrm{PCI}_{t-i}+\sum_{i=1}^{p} \pi_{i}^{\prime} \Delta \mathrm{MMI}_{t-i}+\sum_{i=1}^{p} \varpi_{i}^{\prime} \Delta \mathrm{CMI}_{t-i}+ \\
\sum_{i=1}^{p} \eta_{i} \Delta \mathrm{CAPY}_{t-i}+\sum_{i=1}^{p} \lambda_{i} \Delta \mathrm{FDIY}_{t-i}+ \\
\rho_{1} \mathrm{PCI}_{t-1}+\vartheta^{\prime} \mathrm{MMI}_{t-1}+\sigma^{\prime} \mathrm{CMI}_{t-1}+\rho_{2} \mathrm{CAPY}_{t-1}+\rho_{3} \mathrm{FDIY}_{t-1}+\nu_{t}
\end{gathered}
$$

The change operator sign $\Delta$ denotes the first difference operator. The $\vartheta^{\prime}, \sigma^{\prime}$ and $\rho_{1-3}$ 
represent both vector and parameter long-run multipliers related to the long-run relationships. The parameter $C_{1}$ denotes drifts, whereas, the short-run dynamic parameters of the fundamental bound testing approach in equation (2) are represented by $\delta_{i}, \pi_{i}^{\prime}, \varpi_{i}^{\prime}, \eta_{i}, \lambda_{i}$ and the white noise error denoted by $\nu$. The presence of cointegration (i.e. long-run relationship) is established via the computed F-statistics and also the test of non-acceptance of null hypotheses (no cointegration) against the alternative hypotheses (cointegration). The following null hypothesis and alternative hypothesis are tested based on the above equations:

$$
\begin{array}{llllll}
H_{0}: & \vartheta^{\prime}=0, \quad \sigma^{\prime}=0, & \rho_{1}=0, & \rho_{2}=0, & \rho_{3}=0 & \text { [i.e. no cointegration], and } \\
H_{1}: & \vartheta^{\prime} \neq 0, \quad \sigma^{\prime} \neq 0, \quad \rho_{1} \neq 0, \quad \rho_{2} \neq 0, & \rho_{3} \neq 0 & \text { [i.e. there is cointegration] }
\end{array}
$$

The calculated F-test values are compared with the tabulated upper and lower bounds presented in Narayan (2004). The decision is to reject the no cointegration hypothesis with acceptance of cointegration, if calculated F-values exceed the tabular ones at the upper bound. If they fall below the lower bound, then we accept the null hypothesis of no cointegration. If they fall between the two critical bounds, the outcome becomes inconclusive. Table 5 presents the findings of the ARDL bounds test to cointegration.

\begin{tabular}{|c|c|c|c|c|c|}
\hline \multirow[b]{3}{*}{ Specified model } & \multicolumn{4}{|c|}{$\begin{array}{l}\text { Critical bound } \\
\text { F-statistic values }\end{array}$} & \multirow{3}{*}{$\begin{array}{l}\text { Computed } \\
\text { F-statistics }\end{array}$} \\
\hline & \multicolumn{2}{|c|}{$5 \%$ level } & \multicolumn{2}{|c|}{$10 \%$ level } & \\
\hline & $\mathbf{I}(\mathbf{0})$ & $\mathbf{I}(\mathbf{1})$ & $\mathbf{I}(\mathbf{0})$ & $\mathbf{I}(1)$ & \\
\hline$F_{\mathrm{PCI}}(\mathrm{PCI} \mid \mathrm{BR}, \mathrm{CAPY}, \mathrm{FDIY})$ & 3.23 & 4.35 & 2.72 & 3.77 & $5.5911(k=3)$ \\
\hline$F_{\mathrm{PCI}}(\mathrm{PCI} \mid \mathrm{TBRT}, \mathrm{CAPY}, \mathrm{FDIY})$ & 3.23 & 4.35 & 2.72 & 3.77 & $5.8543(k=3)$ \\
\hline$F_{\mathrm{PCI}}(\mathrm{PCI} \mid \mathrm{BM}, \mathrm{CAPY}, \mathrm{FDIY})$ & 3.23 & 4.35 & 2.72 & 3.77 & $4.5854(k=3)$ \\
\hline$F_{\mathrm{PCI}}(\mathrm{PCI} \mid \mathrm{BR}, \mathrm{TBRT}, \mathrm{BM}, \mathrm{CAPY}, \mathrm{FDIY})$ & 2.62 & 3.79 & 2.26 & 3.35 & $4.6007(k=5)$ \\
\hline$F_{\mathrm{PCI}}(\mathrm{PCI} \mid \mathrm{MYC}, \mathrm{CAPY}, \mathrm{FDIY})$ & 3.23 & 4.35 & 2.72 & 3.77 & $4.5436(k=3)$ \\
\hline$F_{\mathrm{PCI}}(\mathrm{PCI} \mid \mathrm{TSTY}, \mathrm{CAPY}, \mathrm{FDIY})$ & 3.23 & 4.35 & 2.72 & 3.77 & $4.5259(k=3)$ \\
\hline$F_{\mathrm{PCI}}(\mathrm{PCI} \mid \mathrm{SMTR}, \mathrm{CAPY}, \mathrm{FDIY})$ & 3.23 & 4.35 & 2.72 & 3.77 & $4.7120(k=3)$ \\
\hline$F_{\mathrm{PCI}}(\mathrm{PCI} \mid \mathrm{MCY}, \mathrm{TSTY}, \mathrm{SMTR}, \mathrm{CAPY}, \mathrm{FDIY})$ & 2.62 & 3.79 & 2.26 & 3.35 & $4.4829(k=3)$ \\
\hline
\end{tabular}

Table 5: Cointegration result from the ARDL bounds test framework

Note: $k$ represents the total number of explanatory variables.

Source: Authors' Compilation (2020).

In computing the F-statistical values, the study depends on the Akaike Info Criterion to automatically select the order of the ARDL models. From Table 5 , all the computed Fstatistics are higher than the tabulated statistics of the critical upper bounds by Narayan (2004) at 5\% critical levels. It means that we can reject the no-cointegration hypothesis. The implication is that there exists sufficient proof for a steady and unique long-run relationship among financial market development (i.e. money and capital markets) and real income per capita. 


\section{Empirical Results and Discussion}

The estimation outcomes of the long-run and short-run coefficients including the diagnostic and stability tests are presented in Tables 6 and 7 respectively. In Table 6, models I-III report the results of individual coefficients of the money market indicators with the control variables, whereas the joint relationship of the series is depicted in model IV. The results show that monetary policy rate measuring bank rate and total liquidity have adverse and insignificant effect on real per capita income when they are not augmented with other money market indicators. The results further show direct relationship when other money market indicators are considered. Similarly, the estimates are not statistically significant at $5 \%$. Furthermore, the parameter of Treasury bills rate has a negative and significant value which indicates that a lower rate of the money market instrument has direct and statistically significant impact on income growth. This is in line with expectation of treasury bills rate. In magnitude, a $10 \%$ decrease in treasury bills rate leads to an improvement in real income per capita by $1.38 \%$ and $3.33 \%$ before and after augmented with other money market indicators respectively. However, the coefficient of capital investment does not follow the theoretical expectation. It may be due to out of date fixed assets and its diminishing return. Yet, the FDI parameters have the expected signs which are also statistically significant at $5 \%$ level. Therefore, their effect on output growth is significant as they indicate long-term capital inflow to Ghana. Table 6 shows that a $10 \%$ increase in FDI inflows into Ghana causes a $6.91 \%$ rise in real income per capital.

The individual and joint coefficients of capital market indicators on real income per capita are reported in Models V-VIII. The negative and insignificant coefficient of market capitalization signifies that its impact on economic growth seems negligible in the longrun. It is at variance with the findings of Shahbaz et al. (2008) which suggested direct and significant influence of market capitalization on output growth in Pakistan. The findings of the present study also indicate that the total amount of stock traded coefficient is statistically insignificant but it positively influences economic growth. This negates the findings of Aboudou (2009) for WAMU countries that found income growth being driven by total stocks traded volume. However, the coefficients of stock market turnover show both direct and (indirect) insignificant impact on overall income growth before and (after) augmenting with other capital market indicators respectively. The intuition suggests that capital market development does not significantly affect the Ghanaian economy. This is in tune with the result of Owusu and Odhiambo (2014b), which attributed the negative relationship to the illiquid nature of the capital market assets including the magnitude of financial instrument in the country. It also supports the results of Azarmi et al. (2005) that the stock market insignificantly influenced output growth in India between 1981 and 2001. It then contradicts the results of such scholars as Asante et al. (2011); Dziwornu and Awunyo-Vitor (2013); Churchill et al. (2013); Acquah-Sam and Salami (2014) among others. 
Table 6: Long- and Short-run Estimates from ARDL bounds test

\begin{tabular}{|c|c|c|c|c|c|c|c|c|}
\hline \multirow{2}{*}{$\begin{array}{l}\text { Independent } \\
\text { variables }\end{array}$} & \multicolumn{8}{|c|}{ Dependent variable: Real Income Per Capita } \\
\hline & $\mathbf{I}$ & II & III & IV & $\mathbf{V}$ & VI & VII & VIII \\
\hline \multicolumn{9}{|c|}{ Estimates of long-run parameters } \\
\hline Intercept & $\begin{array}{l}14.594 \\
(9.778)\end{array}$ & $\begin{array}{l}13.283 \\
(8.015)\end{array}$ & $\begin{array}{l}-1.190 \\
(3.827)\end{array}$ & $\begin{array}{c}1.873 \\
(1.777)\end{array}$ & $\begin{array}{c}9.877 \\
(8.854)\end{array}$ & $\begin{array}{l}-2.292 \\
(3.154)\end{array}$ & $\begin{array}{c}14.40 \\
(14.79)\end{array}$ & $\begin{array}{c}6.413 \\
(10.40)\end{array}$ \\
\hline $\mathrm{BR}$ & $\begin{array}{l}-0.091 \\
(0.075)\end{array}$ & & & $\begin{array}{c}0.270 \\
(0.188)\end{array}$ & & & & \\
\hline TBRT & & $\begin{array}{c}-0.138 \\
(0.061)^{* *}\end{array}$ & & $\begin{array}{c}-0.333 \\
(0.178)^{*}\end{array}$ & & & & \\
\hline $\mathrm{BM}$ & & & $\begin{array}{l}-0.020 \\
(0.039)\end{array}$ & $\begin{array}{c}0.092 \\
(0.086)\end{array}$ & & & & \\
\hline $\mathrm{MCY}$ & & & & & $\begin{array}{l}-0.100 \\
(0.103)\end{array}$ & & & $\begin{array}{l}-0.304 \\
(0.193)\end{array}$ \\
\hline TSTY & & & & & & $\begin{array}{c}0.921 \\
(1.754)\end{array}$ & & $\begin{array}{c}1.081 \\
(0.827)\end{array}$ \\
\hline SMTR & & & & & & & $\begin{array}{c}0.446 \\
(0.416)\end{array}$ & $\begin{array}{l}-0.294 \\
(0.323)\end{array}$ \\
\hline CAPY & $\begin{array}{l}-0.480 \\
(0.369)\end{array}$ & $\begin{array}{l}-0.339 \\
(0.291)\end{array}$ & $\begin{array}{c}0.131 \\
(0.130)\end{array}$ & $\begin{array}{l}-0.113 \\
(0.337)\end{array}$ & $\begin{array}{l}-0.364 \\
(0.370)\end{array}$ & $\begin{array}{c}0.130 \\
(0.143)\end{array}$ & $\begin{array}{l}-0.683 \\
(0.724)\end{array}$ & $\begin{array}{l}-0.231 \\
(0.496)\end{array}$ \\
\hline FDIY & $\begin{array}{c}0.511 \\
(0.234)^{* *}\end{array}$ & $\begin{array}{c}0.372 \\
(0.177)^{*}\end{array}$ & $\begin{array}{c}0.470 \\
(0.128)^{* * *}\end{array}$ & $\begin{array}{c}0.691 \\
(0.189)^{* * *}\end{array}$ & $\begin{array}{c}0.647 \\
(0.227)^{* *}\end{array}$ & $\begin{array}{c}0.487 \\
(0.143)^{* * *} \\
\end{array}$ & $\begin{array}{c}0.597 \\
(0.272)^{* *} \\
\end{array}$ & $\begin{array}{c}0.606 \\
(0.207)^{* *} \\
\end{array}$ \\
\hline \multicolumn{9}{|c|}{ Estimates of short-run parameters } \\
\hline$\Delta \mathrm{PCI}_{-1}$ & $\begin{array}{c}0.173 \\
(0.237)\end{array}$ & $\begin{array}{c}0.102 \\
(0.238)\end{array}$ & $\begin{array}{c}0.371 \\
(0.266)\end{array}$ & $\begin{array}{c}-0.189 \\
-(0.333)\end{array}$ & $\begin{array}{c}0.297 \\
(0.230)\end{array}$ & $\begin{array}{c}0.322 \\
(0.260)\end{array}$ & & $\begin{array}{c}0.318 \\
(0.260)\end{array}$ \\
\hline$\Delta \mathrm{BR}_{-1}$ & $\begin{array}{c}-0.193 \\
(0.106)^{*}\end{array}$ & & & $\begin{array}{c}-0.372 \\
(0.150)^{* *}\end{array}$ & & & & \\
\hline$\Delta \mathrm{TBRT}_{-1}$ & & $\begin{array}{l}-0.005 \\
(0.056)\end{array}$ & & $\begin{array}{c}0.165 \\
(0.119)\end{array}$ & & & & \\
\hline$\Delta \mathrm{BM}_{-1}$ & & & $\begin{array}{l}-0.025 \\
(0.051)\end{array}$ & $\begin{array}{l}-0.006 \\
(0.064)\end{array}$ & & & & \\
\hline$\Delta \mathrm{MCY}_{-1}$ & & & & & $\begin{array}{c}0.110 \\
(0.065)\end{array}$ & & & $\begin{array}{c}0.335 \\
(0.100)^{* *}\end{array}$ \\
\hline$\Delta \mathrm{TSTY}_{-1}$ & & & & & & $\begin{array}{c}1.031 \\
(1.821)\end{array}$ & & $\begin{array}{c}2.788 \\
(1.448)^{* * *}\end{array}$ \\
\hline$\Delta \mathrm{SMTR}_{-1}$ & & & & & & & $\begin{array}{c}0.284 \\
(0.195)\end{array}$ & $\begin{array}{l}-0.218 \\
(0.235)\end{array}$ \\
\hline$\Delta \mathrm{CAPY}_{-1}$ & $\begin{array}{c}-0.069 \\
(0.164)^{* *}\end{array}$ & $\begin{array}{c}0.234 \\
(0.113)^{*}\end{array}$ & $\begin{array}{c}0.164 \\
(0.176)\end{array}$ & $\begin{array}{c}0.261 \\
(0.144)\end{array}$ & $\begin{array}{c}0.351 \\
(0.127)^{* *}\end{array}$ & $\begin{array}{c}0.145 \\
(0.184)\end{array}$ & $\begin{array}{c}0.189 \\
(0.121)\end{array}$ & $\begin{array}{c}0.267 \\
(0.129)^{* * *}\end{array}$ \\
\hline$\Delta$ FDIY $_{-1}$ & $\begin{array}{c}-1.035 \\
(0.350)^{* *}\end{array}$ & $\begin{array}{c}-0.813 \\
(0.302)^{* *}\end{array}$ & $\begin{array}{c}0.506 \\
(0.323)^{*}\end{array}$ & $\begin{array}{c}0.141 \\
(0.042)^{* *}\end{array}$ & $\begin{array}{c}0.871 \\
(0.348)^{* *}\end{array}$ & $\begin{array}{c}0.361 \\
(0.383)\end{array}$ & $\begin{array}{c}-0.792 \\
(0.322)^{* *}\end{array}$ & $\begin{array}{c}-1.061 \\
(0.035)^{* *}\end{array}$ \\
\hline $\operatorname{ECT}(-1)$ & $\begin{array}{c}-0.527 \\
(0.237)^{* *}\end{array}$ & $\begin{array}{c}-0.598 \\
(0.238)^{* *}\end{array}$ & $\begin{array}{c}-0.654 \\
(0.382)^{* *}\end{array}$ & $\begin{array}{c}0.119 \\
(0.033)^{* *}\end{array}$ & $\begin{array}{c}-0.603 \\
(0.23)^{* *}\end{array}$ & $\begin{array}{c}-0.112 \\
(0.038) * *\end{array}$ & $\begin{array}{c}-0.638 \\
(0.272)^{* *}\end{array}$ & $\begin{array}{c}-0.541 \\
(0.155)^{* * *}\end{array}$ \\
\hline
\end{tabular}

Note: ${ }^{*},{ }^{*} \& \&^{* * *}$ indicate significance at $10 \%, 5 \%$ \& $1 \%$ levels respectively.

Source: Authors' Compilation (2020). 
Regarding the short-run estimates, the dynamic estimate of monetary policy rate has a negative and significant value, implying that a low lending rate can improve the country's growth rate. This result is also in line with expectation. More so, the short-run estimate of total liquidity is negative and not statistically significant at $5 \%$, whereas the coefficient of treasury bills rate has a positive, yet still insignificant value at the conventional level. On the other hand, the coefficients of the short-run market capitalization and total stock traded value are positive and significant at 5\%. This means that they have an unconditional impact on real income per capita. It suggests that both capital market indices have the presumed direction in the short-run. In magnitude terms, a $1 \%$ increase in the short-run market capitalization and total stock traded value leads to a higher rate of income per capita growth by $0.34 \%$ and $2.79 \%$ respectively.

In Table 6, the parameter values of the error correction term (ECT) are negative and also statistically significant at the conventional level. Moreover, the ECT values range between $11.2 \%-65.4 \%$. This result means that the convergence rate of long-run equilibrium of output growth in the current year is from roughly $11.2 \%-65.4 \%$ disequilibrium in preceding year's output shocks. Accordingly, it aligns with the earlier findings that a long-run relationship exists among money market, capital market development and overall output growth in Ghana.

Table 7: Stability and Diagnostic Tests of the Models

\begin{tabular}{lcccccccc}
\hline & \multicolumn{7}{c}{ Dependent variable: Real per capita income } \\
\cline { 2 - 9 } Test statistics & $\mathbf{I}$ & II & III & IV & V & VI & VII & VIII \\
\hline Serial correlation & 0.065 & 0.100 & 0.679 & 3.189 & 0.268 & 1.175 & 0.017 & 2.092 \\
& $(0.932)$ & $(0.912)$ & $(0.550)$ & $(0.143)$ & $(0.728)$ & $(0.340)$ & $(0.984)$ & $(0.173)$ \\
Functional form & 1.231 & 1.873 & 1.897 & 1.232 & 1.804 & 1.845 & 1.439 & 2.048 \\
& $(0.208)$ & $(0.087)$ & $(0.079)$ & $(0.207)$ & $(0.083)$ & $(0.086)$ & $(0.172)$ & $(0.174)$ \\
Normality test & 1.189 & 0.626 & 1.054 & 1.078 & 1.182 & 0.805 & 0.631 & 3.027 \\
& $(0.546)$ & $(0.731)$ & $(0.586)$ & $(0.299)$ & $(0.549)$ & $(0.760)$ & $(0.729)$ & $(0.162)$ \\
Heteroskedasticity & 1.079 & 1.373 & 1.087 & 2.028 & 1.378 & 1.177 & 1.724 & 1.088 \\
& $(0.297)$ & $(0.289)$ & $(0.294)$ & $(0.175)$ & $(0.276)$ & $(0.258)$ & $(0.180)$ & $(0.296)$ \\
CUSUM & Stable & Stable & Stable & Stable & Stable & Stable & Stable & Stable \\
CUSUMQ & Stable & Stable & Stable & Stable & Stable & Stable & Stable & Stable \\
\hline
\end{tabular}

Note: The statistics in parenthesis are the p-values of the test results reported above them for the selected stability and diagnostic test approaches. Breusch-Godfrey LM method is employed for serial correlation; Ramsey RESET test is used for functionality form; Histogram for normality test; and Breusch-PaganGodfrey technique is employed for heteroskedasticity test.

Source: Authors' Compilation (2020).

The diagnostic and stability tests of the findings are reported in Table 7. The data in Table 7 show that the estimated models passed all the diagnostic test statistics. The outcomes indicate that the white noise errors are uncorrelated, distributed normally, and appear with the same variance. Also, the functional form test of the models indicates that they are well specified. 
The stability test results of the models using both cumulative sum (CUSUM) and cumulative sum of square (CUSUMQ) are presented in Table 6. The CUSUM test is used to identify the changes in the regression parameters, whereas, the unexpected constant change in the regression coefficients is detected by the CUSUMQ. The outcomes of the CUSUM and CUSUMQ lie inside the critical bound at the conventional level. It implies that the coefficients are stable during the sample years for Ghana. Thus, at $5 \%$ significance level, there is no form of systematic change in the parameter estimates for the periods under study.

\section{Conclusion}

This study is a comparative analysis of the impact of both capital and money markets in the Ghanaian economy within the periods of 1991-2017. We use the dynamic ARDL bounds test approach in the study. Our cointegration result suggests there is a steady and unique long-run relationship among the money and capital markets and output growth in Ghana. For the money market indicators, the findings indicated that a lower monetary policy rate significantly enhanced short-run growth whereas a lesser treasury bills rate significantly drove the country's long-run economic growth. Capital market indicators total stock traded and market capitalisation enhanced short-run output growth positively and significantly. However, all the three indices of capital market did not significantly impact the country's long-run growth. The findings also implied that capital market, being a long-term equity and debt capital, had a short-run impact on the Ghanaian economy while money market, being a short-term debt instrument, enhanced growth both in the short- and in the long-run. The conclusion is that the money market had greater impact on growth in Ghana than the capital market. Thus, the important lesson relearned from this study is that the money market propels the Ghanaian economy better than the capital market. The study, therefore, recommends that appropriate monetary policies, which would sustain the Ghanaian money market, should be initiated and executed to boost output growth. Moreover, the prices of financial assets, that are traded in the stock market, must be well regulated to ensure that both the sellers and the buyers of such stocks are treated fairly. This will boost growth in both markets, enhance overall output growth in the country and lead to fairness in stock price. Finally, efficiency of information flow must be promoted in both markets to remove information asymmetry and aid the pre- and post- stock listings in the market. This will not only improve efficiency in the system but also encourage the entrance of more stakeholders into the market with a view to promoting the overall output growth. 
The publication was co-financed by the "Excellent Science" program of the Minister of

Science and Higher Education (currently Minister of Education and Science).

Dofinansowano z programu "Doskonała nauka" Ministra Nauki i Szkolnictwa Wyższego (obecnie Ministra Edukacji i Nauki).

\section{References}

Aboudou, T. M. (2009). Causality tests between stock market development and economic growth in West African Monetary Union. Economia. Seria Management, 12(2):14-27.

Acquah-Sam, E. and Salami, K. (2014). Effect of capital market development on economic growth in Ghana. European Scientific Journal, 10(7).

Adusei, M. (2014). Does stock market development promote economic growth in Ghana? International Journal of Economics and Finance, 6(6):119-126.

Alimi, Y. O. and Yinusa, O. G. (2016). SME credit financing, financial development and economic growth in Nigeria. African Journal of Economic Review, 4(2):1-15.

Asante, S., Agyapong, D., and Adam, A. M. (2011). Bank competition, stock market and economic growth in Ghana. International Journal of Business Administration, 2(4):33.

Azarmi, T., Lazar, D., and Jeyapaul, J. (2005). Is the Indian stock market a Casino? Journal of Business 83 Economics Research (JBER), 3(4):63-72.

Bank of Ghana (2019). Statistics and Publications: Monetary Times Series Data. Available at: https://www.bog.gov.gh/statistics/time-series-data. Accessed on $30 / 03 / 2019$.

Beck, T., Demirguc-Kunt, A., Levine, R., and Maksimovic, V. (2000). Financial structure and economic development: Firm, industry and country evidence. Technical report, World Bank Working Paper Series, No. 2423.

Beck, T. and Levine, R. (2004). Stock markets, banks, and growth: Panel evidence. Journal of Banking $\&$ Finance, 28(3):423-442.

Bolbol, A. A., Fatheldin, A., and Omran, M. M. (2005). Financial development, structure, and economic growth: the case of Egypt, 1974-2002. Research in International Business and Finance, 19(1):171-194. 
Bonfiglioli, A. and Mendicino, C. (2004). Financial liberalization, bank crises and growth: Assessing the links. Technical report, SSE/EFI Working Paper No. 567.

Brasoveanu, L., Dragota, V., Catarama, D., and Semenescu, A. (2008). Correlations Between Stock Market Development and Economic Growth. Journal of Economic Development, 29(1):33-50.

Charles, A., Mesagan, E. P., and Saibu, M. (2018). Resource endowment and export diversification: Implications for growth in Nigeria. Studies in Business and Economics, 13(1):29-40.

Churchill, R. Q., Arhenful, P., and Agbodohu, W. (2013). Stock market capitalization and economic growth in Ghana. Research Journal of Finance and Accounting, 4(17):23-45.

Cooray, A. (2010). Do stock markets lead to economic growth? Journal of Policy Modeling, 32(4):448-460.

Dickey, D. A. and Fuller, W. A. (1979). Distribution of the estimators for autoregressive time series with a unit root. Journal of the American Statistical Association, 74(366a):427-431.

Durusu-Ciftci, D., Ispir, M. S., and Yetkiner, H. (2017). Financial development and economic growth: Some theory and more evidence. Journal of Policy Modeling, 39(2):290306.

Dziwornu, R. K. and Awunyo-Vitor, D. (2013). Stock Exchange Performance and Economic Growth in Ghana: Is there a Causal Link? Asian Journal of Empirical Research, 3(9):1152-1165.

Echekoba, F. N., Ezu, G. K., and Egbunike, C. F. (2013). The impact of capital market on the growth of the Nigerian economy under democratic rule. Oman Chapter of Arabian Journal of Business and Management Review, 3(2):53-62.

Einchengreen, B. and Leglang, D. (2003). Capital account liberalization and Emerging Markets. Journal of Financial Research, 26:275-299.

Enisan, A. A. and Olufisayo, A. O. (2009). Stock market development and economic growth: Evidence from seven sub-Sahara African countries. Journal of Economics and Business, 61(2):162-171.

Eregha, P. B. and Mesagan, E. P. (2020). Oil resources, deficit financing and per capita GDP growth in selected oil-rich African nations: A dynamic heterogeneous panel approach. Resources Policy, 66:101615.

Gibson, H. D. and Tsakalotos, E. (1994). The scope and limits of financial liberalisation in developing countries: A critical survey. Journal of Development Studies, 30(3):578-628. 
Goldsmith, R. W. (1969). Financial structure and development. Technical report, New Haven, Yale University Press.

Granger, C. W. (1969). Investigating causal relations by econometric models and crossspectral methods. Econometrica, 17:424-438.

Grilli, V. and Milesi-Ferretti, G. M. (1995). Economic effects and structural determinants of capital controls. IMF Staff Papers, 42(3):517-551.

Haug, A. A. (2002). Temporal aggregation and the power of cointegration tests: A Monte Carlo study. Oxford Bulletin of Economics and statistics, 64(4):399-412.

Isola, W. A. and Mesagan, E. P. (2018). Monetary policy and small and medium enterprises' performance in selected West African countries. Romanian Economic Journal, 20(69):14-23.

Levine, R. (1997). Financial Development and Economic Growth: Views and Agenda. Journal of Economic Literature, 35(2):688-726.

Levine, R. and Zervos, S. (1996). Stock Market Development and Long-Run Growth. World Bank Economic Review, 10(2):323-339.

McKinnon, R. I. (1973). Money and capital in economic development. The Brookings Institution: Washington, DC.

Mesagan, E. P., Alimi, O. Y., and Yusuf, I. A. (2018a). Macroeconomic implications of exchange rate depreciation: The Nigerian experience. Managing Global Transition, $16(3): 235-258$.

Mesagan, E. P. and Nwachukwu, M. I. (2018). Determinants of environmental quality in Nigeria: Assessing the role of financial development. Econometric Research in Finance, $3(1): 55-78$.

Mesagan, E. P., Ogbuji, I. A., Alimi, Y. O., and Odeleye, A. T. (2019a). Growth effects of financial market instruments: the Ghanaian experience. Forum Scientiae Oeconomia, $7(4): 67-82$.

Mesagan, E. P., Olunkwa, N., and Yusuf, I. (2018b). Financial development and manufacturing performance: The Nigerian case. Studies in Business and Economics, 13(1):97111.

Mesagan, E. P. and Shobande, O. A. (2016). Role of Apex Banks: The Case of Nigerian Economy. Journal of Economics $\&$ Business Research, 22(2):171-186.

Mesagan, E. P., Unar, A., Idowu, J., and Alamu, A. (2019b). Oil resource abundance in Nigeria and Iran: contrapuntal effect on social and economic welfare. BizEcons Quarterly, 4:3-22. 
Mishra, P. (2020). Role of Finance in Economic Growth in India: An Emperical Analysis. Journal of Business Management \& Quality Assurance (e ISSN 2456-9291), 3(2):23-36.

Mishra, P. K., Mishra, U. S., Mishra, B. R., and Mishra, P. (2010). Capital market efficiency and economic growth: the case of India. European Journal of Economics, Finance and Administrative Sciences, 27(18):130-138.

Narayan, P. K. and Narayan, S. (2013). The short-run relationship between the financial system and economic growth: New evidence from regional panels. International Review of Financial Analysis, 29:70-78.

Nili, M. and Rastad, M. (2007). Addressing the growth failure of the oil economies: The role of financial development. The Quarterly Review of Economics and Finance, 46(5):726-740.

Obstfeld, M., Dornbusch, R., and McKinnon, R. (1995). International currency experience: new lessons and lessons relearned. Brookings Papers on Economic Activity, 1995(1):119-220.

Odhiambo, N. M. (2010a). Interest rate reforms, financial deepening and economic growth in Tanzania: A dynamic linkage. Journal of Economic Policy Reform, 13(2):201-212.

Odhiambo, N. M. (2010b). Stock market development and economic growth in South Africa: An ARDL-bounds testing approach. World Business Institute, pages 1-13.

Omojolaibi, J. A., Mesagan, E. P., and Stanley, N. C. (2016). Globalization and Financial Development in Nigeria. Iranian Economic Review, 20(4):461-478.

Osei, V. (2005). Does the stock market matter in Ghana? A granger-causality analysis. Technical report, Working Paper/Bank of Ghana (WP/BOG)-2005/13, Accra, Ghana.

Owusu, E. L. (2016). Stock market and sustainable economic growth in Nigeria. Economies, 4(25):1-13.

Owusu, E. L. and Odhiambo, N. M. (2014a). Financial liberalisation and economic growth in Nigeria: an ARDL-bounds testing approach. Journal of Economic Policy Reform, $17(2): 164-177$.

Owusu, E. L. and Odhiambo, N. M. (2014b). Stock market development and economic growth in Ghana: an ARDL-bounds testing approach. Applied Economics Letters, 21(4):229-234.

Pesaran, M. H., Shin, Y., and Smith, R. J. (2001). Bounds testing approaches to the analysis of level relationships. Journal of Applied Econometrics, 16(3):289-326. 
Sakyi, D., Commodore, R., and Opoku, E. E. O. (2015). Foreign direct investment, trade openness and economic growth in Ghana: An empirical investigation. Journal of African Business, 16(1-2):1-15.

Samargandi, N., Kutan, A. M., Sohag, K., and Alqahtani, F. (2020). Equity market and money supply spillovers and economic growth in BRICS economies: A global vector autoregressive approach. The North American Journal of Economics and Finance, $51: 101060$.

Schumpeter, J. A. (1911). The theory of economic development; an inquiry into profits, capital, credit, interest, and the business cycle. Harvard University Press, Cambridge. Translated by Opie, R.

Shahbaz, M., Ahmed, N., and Ali, L. (2008). Stock market development and economic growth: ARDL causality in Pakistan. International Research Journal of Finance and Economics, 14(1):182-195.

Shaw, E. S. (1973). Financial deepening in economic development. Oxford University Press: Oxford.

Sims, C. A. (1972). Money, income, and causality. The American Economic Review, $62(4): 540-552$.

Singh, A. (1997). Financial liberalisation, stock markets and economic development. The Economic Journal, 107(442):771-782.

Toda, H. Y. and Yamamoto, T. (1995). Statistical inference in vector autoregressions with possibly integrated processes. Journal of Econometrics, 66(1-2):225-250.

Vazakidis, A. and Adamopoulos, A. (2009). Stock market development and economic growth. American Journal of Applied Sciences, 6(11):1933-1941.

World Development Indicators (2019). World Bank Data on Country Development. Available Online at http://databank. worldbank.org/data/reports . aspx? source= world-development-indicators. Accessed on 25th November, 2019.

Yinusa, O. G. and Alimi, O. Y. (2014). Financial development, poverty and income inequality in Nigeria. LAPAI International Journal of Management \& Social Science (LIJOMASS), 7:75-92.

Yusuf, I. A., Mesagan, E. P., and Amadi, A. N. (2020). Effect of financial deepening on stock market returns: The case of military and democratic post-SAP regimes in Nigeria. BizEcons Quarterly, 6:3-21. 